\title{
Milk composition as technique to evaluate the relative bioavailability of a liquid rumen protected methionine source
}

\author{
L.J. Erasmus ${ }^{1 \#}$, Z. Bester ${ }^{1,2}$ \& R.J. Coertze ${ }^{1}$ \\ ${ }^{1}$ Dept of Animal and Wildlife Sciences, University of Pretoria, P. Bag X20, Hatfield, Pretoria 0028, South Africa \\ ${ }^{2}$ Chemuniqué International (Pty) Ltd, 330 Surrey Ave, Randburg 2194, South Africa
}

(Received 8 December 2012; Accepted 17 May 2013; First published online 15 August 2013)

\begin{abstract}
Rumen protected amino acids (RPAA) are increasingly being used in dairy cattle diet formulation to obtain the required concentrations of lysine and methionine in metabolisable protein for optimal milk and milk protein production. The objective of this study was to evaluate the relative bioavailability of a liquid rumen protected lysine prototype using the milk composition technique. Forty mid-lactation Holstein cows were used in a complete randomised block design experiment and allocated to one of four experimental treatments. The treatments were: (1) Methionine deficient (Met-) diet, (2) Met- diet supplemented with Smartamine M (SMM), (3) Met- diet supplemented with liquid rumen protected prototype (LRPMet) and (4) Met- diet supplemented with DL Met (DLMet), a hydroxyl analogue of methionine. After an adaptation phase all four groups received the Met- diet and thereafter switched over to the four treatments. Cows supplemented with SMM had higher milk protein and milk fat \% compared to the other treatments and increased milk casein \% significantly when compared to the Met-control treatment. The milk protein percentages were 3.06, 3.25, 2.95 and 3.46 and the milk fat percentages 3.84, 3.93, 3.75 and 4.27 for the Met-, LRPMet, DL Met and SMM treatments, respectively. SMM again proved to be the RPAA with a high relative bioavailability, while the LRPMet failed to elicit any milk yield or milk composition response. The milk composition technique proved to be a simple but effective technique to evaluate the bioavailability of rumen protected products or prototypes.
\end{abstract}

Keywords: Milk composition, rumen protected methionine, amino acids, Holstein cows

\#Corresponding author: lourens.erasmus@up.ac.za

\section{Introduction}

Lysine (Lys) and methionine (Met) have been identified as the two most limiting amino acids (AA) for the synthesis of milk and milk protein (NRC, 2001; Weekes et al., 2006). This is because of their low concentrations in most feeds fed to lactating cows, relative to their apparent optimum concentration of $7.2 \%$ Lys and 2.4\% Met in metabolisable protein (MP) (NRC, 2001). In most cases, Met has been shown to be more limiting than Lys. However, Lys can become co-limiting with Met or more limiting than Met, when feeds of maize origin provide most, or all, of the rumen undegradable protein (RUP) in the diet (Schwab, 2010).

To supply additional Met and Lys, methods and technologies had been developed to protect these AA from microbial degradation resulting in the rumen protected AA (RPAA) passing to the abomasum and small intestine where they are released and absorbed. Before commercialisation of such products or prototypes, information is necessary on the relative or apparent bioavailability of the specific AA (Ordway et al., 2009).

In vivo estimates of protein degradation requires cattle with rumen and duodenal cannulas and for in vivo estimation of postruminal availability an additional cannula in the terminal ileum is needed. In vivo estimates are expensive, labour intensive, time consuming and subject to error, associated with the use of 
digestion flow rate and microbial markers and animal variation. Alternative methods for measuring ruminal degradation and postruminal availability of nutrients are needed (Tamminga \& Chen, 2000). The in situ technique for measuring rumen degradation and the mobile bag technique for measuring rumen undegraded protein (RUP) digestibility are alternative techniques, but still require cannulated animals and are unsuitable for evaluating liquid products (Stern et al., 2006).

An alternative non-invasive procedure to estimate the relative bio-availability of RPAA is to measure changes in milk composition (milk composition technique) (Sameulson et al., 2001). It has been demonstrated that (1) content of protein in milk is more responsive than milk yield to supplemented Lys and Met, particularly in post-peak cows, (2) increases in milk protein percentage are independent of milk yield, (3) casein is the most influenced milk protein fraction, and (4) increases in milk protein production to increased supplies of either Lys or Met in MP are the most predictable when the resulting predicted supply of other AA in MP is near or at estimated requirements (NRC, 2001).

It was hypothesised that the relative bio-availability of a liquid RP Met (LRP Met) prototype could be determined, using the milk composition technique, by comparing it to an established RP Met source (Smartamine M) (Adisseo, Inc., Antony, France) and to a feed grade DL-Methionine (Evonik Degussa, Theodore, Alabama, USA) which is not protected against ruminal degradation.

\section{Materials and Methods}

Forty high producing early- to mid-lactation multiparous Holstein cows were used in a randomised complete block design experiment. The cows were grouped into 10 blocks of four cows each. Within each of the 10 blocks the cows were allocated to one of four dietary treatments based on the average milk during the two weeks preceding the study, days in milk and parity. The mean days in milk for the four treatment groups were 98, 114, 102 and 111 days, respectively. The four experimental treatments were a Met deficient diet (Met-), and the Met- diet supplemented with either Smartamine M (SMM), the LRPMet prototype or DL Met. The Lys : Met ratio (\%MP) in the Met- diet was $7.2: 1.72$ (4.18:1) (Table 1). The CPM Dairy

Table 1 Ingredient and chemical composition of the methionine deficient (Met-) control diet ${ }^{1}$

\begin{tabular}{|c|c|c|c|}
\hline Ingredient & $\begin{array}{c}\mathrm{g} / \mathrm{kg} \\
\mathrm{DM}\end{array}$ & $\begin{array}{c}\text { Chemical } \\
\text { composition }^{2}\end{array}$ & $\mathrm{~g} / \mathrm{kg} / \mathrm{DM}$ \\
\hline Lucerne hay & 313 & Crude protein (CP) & 185.5 \\
\hline Sorghum & 255 & $\mathrm{RUP}^{4}$ (\% CP) & 50.2 \\
\hline Whole cottonseed & 102 & $\mathrm{ME}^{4}(\mathrm{MJ} / \mathrm{kg})$ & 11.2 \\
\hline Wheaten bran & 98 & $\mathrm{NDF}^{4}$ & 316 \\
\hline Citrus pulp dried & 59 & $\mathrm{NFC}^{5}$ & 381 \\
\hline Sugar cane molasses & 51 & Starch & 164 \\
\hline Blood meal & 43 & Ether extract & 65 \\
\hline Soybean oilcake meal & 39 & Calcium & 8.9 \\
\hline Megalac $^{\mathrm{TM}}$ & 24 & Phosphorus & 4.1 \\
\hline Sodium bicarbonate & 8 & Lys (\% MP) & 1.72 \\
\hline Salt & 5 & Met (\% MP) & 7.2 \\
\hline Vit + Min premix ${ }^{3}$ & 4 & Lys : Met & $4.18: 1$ \\
\hline \multicolumn{4}{|c|}{$\begin{array}{l}{ }^{1} \text { Experimental diets: Met-diet supplemented with either LRPMet, Smartamine M or DLMet to each provide } \\
\text { a similar amount (23.6 kg) of potentially available Met resulting in an optimal ratio of Lys : Met (3 : 1) in MP. } \\
{ }^{2} \text { Predictions from CPM Dairy database. } \\
{ }^{3} \text { Vitamin and mineral content/kg DM: } 45 \mathrm{mg} \text { Zn; } 15 \mathrm{mg} \mathrm{Cu;} 22 \mathrm{mg} \text { Mn; } 0.25 \mathrm{mg} \text { Se; } 0.1 \mathrm{mg} \text { Co; } 0.28 \mathrm{mg} \text { I; } \\
2900 \text { IU vitamin A; } 800 \text { IU vitamin D; } 20 \mathrm{mg} \text { vitamin E. } \\
{ }^{4} \text { RUP: rumen undegraded protein; ME: metabolisable energy; NDF: neutral detergent fibre; } \\
{ }^{5} \text { NFC (non-fibre carbohydrates) (\% DM) = } 100 \text { - (CP + Fat + Ash + (NDF - NDFIP)). }\end{array}$} \\
\hline
\end{tabular}


programme was used to formulate and evaluate the Met- diet and determine the additional amount of post ruminal available methionine needed to achieve the desired Lys : Met ratio of $3: 1$ or $7.2 \%$ and $2.4 \%$ of MP. Based on product specifications the Met- diet was supplemented with either $145 \mathrm{~mL} / \mathrm{cow} /$ day of LRPMet, $37.3 \mathrm{~g}$ of SMM/cow/day or $23.8 \mathrm{~g}$ of DL Met/cow/day to each provide a similar amount of $23.6 \mathrm{~g}$ of potentially available Met and therefore the optimal Lys : Met of $3: 1$ in MP. The ingredient and chemical composition of the Met- diet are shown in Table 1.

The experiment consisted of three experimental periods, namely an adaptation period of seven days and two experimental periods of 21 days each during which production was monitored and samples taken. During period 1, the adaption phase, all cows were fed a commercial total mixed ration (TMR) (170 g CP, 370 g NFC, 11.1 MJ ME/kg DM) (Afgri Limited, 12 Byles Bridge Boulevard, Centurion 0046). The TMR was fed three times per day and fresh water available ad libitum. Cows were milked three times per day in a 10 point Herringbone system equipped with a DeLavalAlpro milking system (DeLaval (Pty) Ltd, Pinetown, South Africa). Calanheadgates were used to measure daily individual feed intake. Milk production was recorded on a daily basis and milk samples were taken every second day to be analysed for fat protein, lactose and SCC using the System 4000 Infrared Analyzer (Foss Electric, Hillerod, Denmark). During period 2 the Met- diet was fed for 21 days to all four groups of cows. Additional milk samples were taken on day 21 of period 2 and analysed for $\mathrm{N}$ fractions (casein, whey, NPN). Milk samples were analysed for urea by the colorimetric-enzymatic method, using Chemspec 150 (Bentley Instruments Inc, Chaska, MN, USA), noncasein N (Lynch et al., 1998) and NPN concentrations (AOAC, 1995 method 332 12; 991 21). Casein concentrations were obtained by difference. During period 3, three of the four groups receiving the Met(control) diet during period 2 were supplemented with either DL Met, SMM or LRPMet for 21 days. Supplements were mixed into small amounts of TMR $(2 \mathrm{~kg})$ twice daily and fed directly after cows returned from the milking parlour. Additional TMR was only fed for ad libitum consumption after all of the $2 \mathrm{~kg}$ TMR with supplement was consumed. Production data monitoring and sampling were the same as in period 2.

Data were analysed as a randomised complete block design with the General Linear Model (GLM), (SAS, 2006) for an analysis of variance to determine difference between treatments and periods. Means and standard error of the means (SEM) were calculated. The significance of difference between means was determined by the Fischer's protective test (Samuels, 1989). Significance was declared at $P<0.05$ and tendencies at $P<0.10$.

The linear model used is described by the following equation:

$$
\mathrm{Y}_{\mathrm{ijk}}=\mu+\mathrm{T}_{\mathrm{i}}+\mathrm{P}_{\mathrm{j}}+\mathrm{B}_{\mathrm{k}}+\mathrm{TP}_{\mathrm{ij}}+\mathrm{e}_{\mathrm{ijk}}
$$

Where $\mathrm{Y}_{\mathrm{ijk}}=$ variable studied during the period

$\mu \quad=$ overall mean of the population

$\mathrm{T}_{\mathrm{i}}=$ effect of the ithe treatment

$\mathrm{Pj}=$ effect of the jthe period

$\mathrm{B}_{\mathrm{k}}=$ effect of the kthe block

$\mathrm{E}_{\mathrm{ijk}}=$ error associated with each $\mathrm{Y}$

Average days in milk as covariant were included in the original model. No significant interactions with treatments were found.

\section{Results and Discussion}

The effect of AA supplementation on production parameters is shown in Table 2. Milk yield was not affected by treatment and did not differ within any of the periods $(P>0.05)$. This was expected since milk yield responses to Lys and Met supplementation are more common in early-lactation than in mid- or latelactation cows (Schwab \& Ordway, 2001), as was the case in this study. Similarly, Blum et al. (1991) and Krober et al. (2001) found only minor effects of additional Met on milk yield. For all treatments DMI declined $(P<00.5)$ when comparing periods 1 and 2 within treatment, most probably because the Met- diet contained $4 \%$ bloodmeal which is high in Lys, but unpalatable. During period 3 the cows possibly got accustomed to the taste and only cows receiving the LRPMet supplement had a lower DMI when compared 
to period 2 within treatments $(P<0.05)$. Donkin et al. (1989) and Wang et al. (2009) also reported no change in DMI after RPAA supplementation.

Table 2 Effect of methionine (Met) supplementation on milk yield, dry matter intake (DMI) and milk composition measured over and within periods*

\begin{tabular}{|c|c|c|c|c|c|}
\hline \multirow{2}{*}{ Parameter } & \multicolumn{4}{|c|}{${ }^{1}$ Treatments } & \multirow{2}{*}{ SEM } \\
\hline & Met- & LRPMet & DLMet & SMM & \\
\hline \multicolumn{6}{|c|}{ Milk yield (kg /day) } \\
\hline P1 & 35.72 & 36.05 & 36.48 & 35.36 & 0.99 \\
\hline $\mathrm{P} 2$ & 35.74 & 36.55 & 36.96 & 35.65 & 0.99 \\
\hline P3 & 35.02 & 35.13 & 36.34 & 35.07 & 0.99 \\
\hline \multicolumn{6}{|c|}{ DMI (kg /cow /day) } \\
\hline P1 & $25.03^{\mathrm{a}}$ & $23.91^{\mathrm{ab}}{ }_{1}$ & $22.7_{1}^{\mathrm{bc}}$ & $22.55^{c}{ }_{1}$ & 0.53 \\
\hline P2 & $19.82_{2}$ & $20.40_{2}$ & $20.47_{2}$ & $19.51_{2}$ & 0.53 \\
\hline P3 & $19.41_{2}$ & $18.79_{3}$ & $19.49_{2}$ & $18.73_{2}$ & 0.53 \\
\hline \multicolumn{6}{|c|}{ Milk Protein (\%) } \\
\hline P1 & $3.10^{\mathrm{ab}}$ & $3.16^{\mathrm{ab}}$ & $3.00^{\mathrm{b}}$ & $3.23^{\mathrm{a}}$ & 0.17 \\
\hline $\mathrm{P} 2$ & $2.98^{\mathrm{b}}$ & $3.15^{\mathrm{a}}$ & $2.94^{\mathrm{b}}$ & $3.22^{\mathrm{a}}{ }_{1}$ & 0.17 \\
\hline P3 & $3.06^{\mathrm{b}}$ & $3.25^{\mathrm{b}}$ & $2.95^{\mathrm{c}}$ & $3.46^{\mathrm{a}}{ }_{2}$ & 0.17 \\
\hline \multicolumn{6}{|l|}{ Fat (\%) } \\
\hline P1 & 3.54 & 3.65 & 3.62 & $3.80_{3}$ & 0.14 \\
\hline $\mathrm{P} 2$ & $3.79^{c}$ & $3.97^{\mathrm{ab}}$ & $3.82^{\mathrm{bc}}$ & $4.14^{\mathrm{a}}{ }_{1}$ & 0.14 \\
\hline P3 & $3.84^{\mathrm{bc}}$ & $3.93^{\mathrm{ab}}$ & $3.75^{\mathrm{c}}$ & $4.27^{\mathrm{a}}{ }_{2}$ & 0.14 \\
\hline \multicolumn{6}{|l|}{ Lactose (\%) } \\
\hline P1 & $4.83_{1}$ & $4.76_{1}$ & $4.80_{1}$ & $4.76_{1}$ & 0.06 \\
\hline P2 & $4.70_{12}$ & $4.64_{1}$ & $4.73_{12}$ & $4.63_{1}$ & 0.06 \\
\hline P3 & $4.65^{\mathrm{a}}{ }_{2}$ & $4.48^{\mathrm{bc}}{ }_{2}$ & $4.62^{\mathrm{ab}}$ & $4.43^{\mathrm{c}}{ }_{2}$ & 0.06 \\
\hline
\end{tabular}

\footnotetext{
${ }^{1}$ Treatments: Methionine deficient diet (Met-); Met- diet supplemented with liquid rumen protected methionine (LRPMet); Met- diet supplemented with Smartamine M (SMM); Met- diet supplemented with DL-Methionine (DLMet).

${ }^{\text {abcd }}$ Row means with different superscript differ $(P<0.05)$.

${ }_{123}$ Column Means with different subscripts differ $(P<0.05)$.

${ }^{\mathrm{E}}$ Standard error of least square means.

* During P1 cows received a standard TMR, during P2 the Met- diet and during P3 the respective Met supplements in addition to the Met- diet.
}

During period 1 milk protein \% was higher $(P<0.05)$ for cows in the SMM group when compared to cows in the DLMet group, but did not differ from the other treatments. During period 3 cows receiving the SMM treatment had the highest milk protein \% at 3.46\%, and differed $(P<0.05)$ from the other treatments. Chapoutot et al. (1992) clearly demonstrated that milk protein percentage is more sensitive than milk yield to improved concentrations of Lys and Met in MP of post-peak lactation cows. They observed that 37 cows of forty cows responded with greater milk protein content and only 16 cows responded with more milk after RPLys + Met supplementation. In support of our results Noftsger \& St-Pierre (2003) and Chen et al. (2009) found significant increases in milk protein \% by increasing Met in MP by $21 \%$ and 19\%, respectively, in order to achieve a more favourable Lys : Met ratio of $3: 1$. Results from the present study are furthermore supported by Patton (2010) who conducted a meta-analysis involving 36 studies where RP Met was 
supplemented. Milk protein \% was consistently increased with minor effects on dry matter intake (DMI) and milk production.

Milk fat \% did not differ between treatment groups during period 1, but was highest for cows supplemented with SMM during period 3. Increases in milk fat have been observed in postruminal infusion studies (Socha et al. 1994) or in several studies where Met was supplied in RP form (Yang et al., 1996; Wang et al., 2010). It is unclear why increased amounts of Met and Lys in MP only sometimes increase fat content in milk. One possibility might be positive effects of Met on the novo synthesis of short- and medium chain fatty acids in the mammary gland. Another possibility may relate to the role of AA in the intestinal and hepatic synthesis of chylomicrons and very low density lipoproteins (NRC, 2001).

Within periods, milk lactose was not affected by treatment, but values were lower $(P<0.05)$ during period 3 compared to period 1 , most probably because of the lower supply of glucogenic precursors brought about by the lower DMI.

The effect of AA supplementation on the magnitude of change in milk components, when comparing different periods/dietary changes is shown in Table 3. The magnitude of change in milk fat \% and milk protein \% between treatments did not differ $(P>0.05)$ when comparing the adaptation diet and the Met- diet. When changing from the Met- diet to the AA supplemented diets, cows supplemented with SMM responded with an average increase of $0.24 \%$ protein units which differed from other treatments $(P<0.05)$. The magnitude of change in milk fat \% when changing from the Met- to the AA supplemented diets were not different between treatments $(P>0.05)$.

Table 3 Effect of methionine (Met) supplementation on the magnitude of change in milk components (\% units) when comparing differences between treatments within and between periods

\begin{tabular}{|c|c|c|c|c|c|}
\hline \multirow{2}{*}{ Parameter } & \multicolumn{4}{|c|}{${ }^{1}$ Treatments } & \multirow{2}{*}{$\mathrm{SEM}^{\mathrm{E}}$} \\
\hline & Met- & LRPMet & DLMet & SMM & \\
\hline \multicolumn{6}{|c|}{ Milk protein (\%) } \\
\hline P1-2* & $-0.12_{1}$ & -0.01 & -0.06 & $-0.01_{1}$ & 0.054 \\
\hline P2-3 & $0.08_{2}^{\mathrm{a}}$ & $0.09^{\mathrm{a}}$ & $0.01^{\mathrm{a}}$ & $0.24_{2}^{\mathrm{b}}$ & 0.054 \\
\hline \multicolumn{6}{|l|}{ Casein (\%) } \\
\hline P2 & $2.04^{\mathrm{bc}}{ }_{1}$ & $2.11_{1}^{\mathrm{ab}}$ & $2.02^{\mathrm{bc}}{ }_{1}$ & $2.24_{1}^{\mathrm{a}}$ & 0.07 \\
\hline P3 & $2.29^{\mathrm{b}}{ }_{2}$ & $2.49^{\mathrm{a}}$ & $2.27_{2}^{\mathrm{b}}$ & $2.64^{\mathrm{a}}{ }_{2}$ & 0.07 \\
\hline P2-3 & $0.25^{\text {bd }}$ & $0.38^{\text {acd }}$ & $0.25^{\mathrm{bc}}$ & $0.40^{\mathrm{a}}$ & 0.07 \\
\hline \multicolumn{6}{|l|}{ Fat (\%) } \\
\hline P1-2 & 0.25 & $0.32_{1}$ & $0.21_{1}$ & 0.34 & 0.09 \\
\hline P2-3 & 0.05 & $-0.04_{2}$ & -0.072 & 0.13 & 0.09 \\
\hline
\end{tabular}

${ }^{1}$ Treatments: Methionine deficient diet (Met-); Met- diet supplemented with liquid rumen protected methionine (LRPMet); Met- diet supplemented with Smartamine M (SMM); Met- diet supplemented with DL-Methionine (DLMet).

abcd Row means with different superscript differ $(P<0.05)$.

${ }_{123}$ Column Means with different subscripts differ $(P<0.05)$.

${ }^{\mathrm{E}}$ Standard error of least square means.

* During P1 cows received a standard TMR, during P2 the Met- diet and during P3 the respective Met supplements in addition to the Met- diet. For casein only the difference between periods 2 and 3.

The \% casein in milk was higher $(P<0.05)$ for cows supplemented with SMM and LRPMet and the magnitude of change when comparing the Met- and AA supplemented diets was also higher for cows receiving the SMM and LRPMet diets. The \% whey protein did not differ between treatments after Met supplementation, but the milk NPN \% was higher for the Met- diet when compared to the LRPMet and SMM supplemented diets. Similarly, Trinacty et al. (2009) found Lys, Met or Lys + Met supplemented cows to 
have an increased $(P<0.05)$ casein \% when compared to unsupplemented cows. Although it is known that casein is the most influenced milk protein fraction (NRC, 2001) a limited number of samples on $\mathrm{N}$ fractions in this study calls for caution when interpreting results.

Supplementation with SMM increased $(P<0.05)$ milk fat and protein when compared to other treatments and increased milk casein when compared to cows receiving the Met- diet. These results therefore suggest that SMM was effective in improving the Lys : Met ratio in MP, while it appears that the LRPMet prototype failed to elicit any response. This could be due to the LRPMet prototype not being properly protected against rumen degradation, not being available for absorption in the SI, or due to ruminal overprotection, or a combination of these factors.

\section{Conclusion}

This experiment proved milk composition, especially milk protein percentage and to a lesser degree milk $\mathrm{N}$ fractions (partly due to cost implications) and milk fat, to be an effective technique for evaluating the relative bioavailability of either liquid or solid RPMet products. This technique could be used as a screening test before the onset of long term expensive lactation studies.

\section{References}

AOAC, 1995. Official Methods of Analysis. $16^{\text {th }}$ ed Association of Analytical Chemists. Arlington, V.A., USA.

Blum, J.W., Buckmaier, R.M. \& Jans, F., 1999. Rumen protected methionine fed to dairy cows: bioavailability and effects on plasma amino acid pattern and plasma metabolite and insulin concentrations. J. Dairy Sci. 82, 1991-1998.

Chapoutot, P., Schmidely, P., Sauvant, D., Robert, J.C. \& Sloan, B., 1992. Influence of a ruminally protected blend of methionine and lysine (ML) on the dairy cow nutrition and production. J. Dairy Sci. 75 (Suppl. 1), 199 (Abstr.).

Chen, J., Broderick, G., Luchini, D., Sloan, B. \& Devillard, E., 2009. Effect of metabolisable lysine and methionine concentrations on milk production and nitrogen utilisation in lactating dairy cows. J. Dairy Sci. 92 (Suppl. 1), 151 (Abstr.).

Donkin, S.S., Varga, G.A., Sweeney, T.F. \& Muller, L.D., 1989. Rumen protected methionine and lysine: effects on animal performance, milk protein yield and physiological measures. J. Dairy Sci. 72, 1484-1491.

Krober, T.F., Sutter, F., Senn, M., Langhans, W. \& Kreuzer, M., 2001. Effects of supplying leucine and methionine to early lactating cows fed silage-concentrate based diets with a calculated deficiency in leucine and methionine. Anim. Res. 50, 5-20.

Lynch, J.M., Barbano, D.M. \& Flemming, J.R., 1998. Indirect and direct determination of the casein content of milk by Kjeldahl nitrogen analysis collaborative study. J. AOAC 81, 763-774.

National Research Council, 2001. Nutrient requirements of dairy cattle. $7^{\text {th }}$ Rev. Ed. Natl. Acad. Sci., Washington D.C., USA.

Noftsger, F. \& St-Pierre, N.R., 2003. Supplementation of methionine and selection of highly digestible rumen undegradable protein to improve nitrogen efficiency for milk production. J. Dairy Sci. 86, 958-969.

Ordway, R.S., Boucher, S.E., Whitehouse, N.L., Schwab, C.G. \& Sloan, B.K., 2009. Effects of providing two forms of supplemental methionine to periparturientHolstein dairy cows on feed intake and lactation performance. J. Dairy Sci. 92, 5154-5166.

Patton, R.A., 2010. Effect of rumen protected methionine on feed intake, milk production, true milk protein concentration and true milk protein yield, and the factors that influence these effects: A meta-analysis. J. Dairy Sci. 93, 2105-2118.

Sameuls, M.L., 1980. Statistics for Life Sciences. Collier McMillan Publishers, London.

Sameulson, D.J., Denise, S.K., Roffler, R., Ax, R.L. \& Armstrong, D.V., 2001. Response of Holstein and Brown Swiss cows fed alfalfa at 2 stages of lactation. J. Dairy Sci. 84, 917-928.

Schwab, C.G., 2010. Balancing diets for amino acids: Nutritional, environmental and financial implications. Pages 1-13 in Proc. Tri-State Dairy Nutr. Conf.

Schwab, C.G. \& Ordway, R.S., 2001. Amino acid nutrition of dairy cows.Proc. $36^{\text {th }}$ Annual Pacific Northwest.Nutrition Conf., Boise, I.D., USA. 
Socha, M.T., Schwab, C.G., Putnam, D.E., Kierstead, N.A., Whitehouse, N.L., Garthwaite, B.D. \& Duchharme, G.A., 1994. Determining methionine requirements of dairy cows during midlactation by psotruminally infusing incremental amounts of methionine. J. Dairy Sci. 77 (Suppl. 1), 92 Abstr.

SAS, 2006. Statistical Analysis Systems, Users Guide. Statistics version 9. SAS Institute Inc. Cary N.C., USA.

Stern, M.D., Bach, A. \& Calsamiglia, S., 2006. New concepts in protein nutrition of ruminants. In: Proc. Southwest Nutr. Mgmt. Conf., Tempe AZ, USA. pp. 45-66.

Tamminga, S. \& Chen, X.B., 2000. Animal based techniques for estimation of protein value of forages. Chapter 11 in: Forage Evaluation in Ruminant Nutrition. Eds: Givens, D.I., Owen, E., Axford, R.F.E. \& Omed, H.M., CADI Publishing, Walling Ford, UK.

Trinacty, J., Krizova, L., Richter, M., Cerny, V. \& Riha, J., 2009. Effect of rumen protected methionine, lysine or both on milk production and plasma amino acids of high yielding dairy cows. Czech J. Anim. Sci. 54, 239-248.

Wang, C., Liu, H.Y., Wang, Y.M., Yang, Z.Q., Liu, J.X., Wu, Y.M., Yan, T. \& Ye, H.W., 2010. Effects of dietary supplementation of methionine and lysine in milk production and nitrogen utilisation in dairy cows. J. Dairy Sci. 93, 3661-3670.

Weekes, T.L., Luimes, P.H. \& Cant, J.P., 2006. Response to amino acid imbalances and deficiencies in lactating cows. J. Dairy Sci., 89, 2177-2187.

Yang, C.M.J., Schingoethe, D.J. \& Casper, D.J., 1986. Protected methionine and heat treated soybean meal for high producing dairy cows. J. Dairy Sci. 69, 2348-2357. 